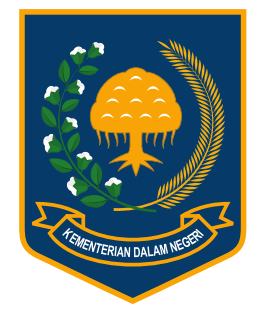

Jurnal Bina Praja 8 (1) (2016): 83-95

Jurnal Bina Praja

e-ISSN: 2503-3360 | p-ISSN: 2085-4323

Accreditation Number

735/AU2/P2MI-LIPI/04/2016

http://jurnal.kemendagri.go.id/index.php/jbp/index

\title{
EVALUATION OF JOINT REGULATION OF THE Minister of RELigion AND Minister of HoME AFFAIRS No. 9 AND 8 OF 2006: Study on Maintenance of Religious HaRmony Policy
}

\author{
Herman Ya'arozatulo Harefa ${ }^{1, *}$ \\ ${ }^{1}$ Research and Development Agency, Ministry of Home Affairs (BPP Kemendagri) \\ Jl. Kramat Raya No. 132, Senen, Jakarta Pusat
}

Received: 1 February 2016; Accepted: 10 May 2016; Published online: 31 May 2016

\begin{abstract}
This study aims to evaluate the implementation of the regulation in the province of East Java. The method used in this study is naturalistic or qualitative with a descriptive explanation. The study result shows that in general, the implementation of the regulation in the province of East Java has not been effective. Factors that affect, among others, are the lack of commitment of in implementing the regulation, weak socialization of the regulation, weak law enforcement, and the lack of multicultural education to the community. The policy that needs to be implemented is mainly of the regulation needs to be improved to become a Law. The approval of the existing Draft Law on the Protection of Religious Community needs to be accelerated.
\end{abstract}

Keywords: protection, religious harmony, regulation socialization.

\section{INTRODUCTION}

In Law No. 23 of 2014 article 25 paragraph 1 letter $\mathrm{c}$ is stated that the government's general affairs include, among other, harmony development of inter-ethnic and between ethnics, faiths, races, and other groups in order to achieve security stability at local, regional, and national levels. Thus, fostering religious harmony is one of the government's public affairs. This affair is conducted by governors and regents/mayors in their respective work region. To carry out this business, governors and regents/ mayors are assisted by vertical institutions. In carrying out this matter, the governor is responsible to the President through the Minister and the regent/mayor is responsible to the Minister through the Governor as the representative of the central government. Regent/mayor in carrying out this matter at the district level delegates the implementation to camat (sub-district head).

Actually, the technicality regarding specific implementation for the affairs of religious harmony has been set in the Joint Regulation of the Minister of Religious Affairs and the Minister of Home Affairs No. 9 and No. 8 of 2006 (PBM 2006) on Guidelines for the Implementation of the Tasks of Regional Head/Deputy Head In Maintaining Religious Community Harmony, Empowerment of Forum for Religious Harmony, and the Establishment of Houses of Worship.

The substances regulated in PBM 2006 are: fostering religious harmony, empowerment of the Forum for Religious Harmony (FKUB), the establishment of houses of worship, a temporary permit for the utilization of building, and dispute resolution. The embodiment of those five matters should be in "a set of interrelation by substance" if we are to meet the management of religious harmony in Indonesia in order to maintain national unity.

The existence of the above-mentioned PBM 2006 is important because Indonesia is a pluralistic nation, composed of various tribes, religions, races, and ethnicities. Moreover, Indonesia's population amounts to 237 Million People (CBS, 2010), which is spread across 17,508 islands from Sabang to Merauke. These conditions make Indonesia have very high potential for conflict, one of them is a conflict with religious backgrounds.

\footnotetext{
* Corresponding Author

Phone : +6281319936144

Email : harefa1972@gmail.com
} 
In addition, the PBM 2006 regulation is also associated with religious rights, which is the human rights that can not be reduced under any circumstances. Everyone is free to choose a religion and to worship according to his religion. Therefore, the state must guarantee the independence of each citizen to profess his own religion and to worship according to his religion or belief.

In the above context, the government is obliged to protect every citizen's effort to implement the teachings of religion and worship of its adherents, as long as they do not contradict the legislation, do not abuse or tarnish religion, and do not disturb the peace and public order.

So, the Government has a duty to provide guidance and service so that every citizen in implementing their religion teachings can take place peacefully, smoothly, and orderly. In this regard, the direction of government policy in national development in the field of religion, among others, is to increase the quality of religious service and understanding, religious life, as well as to increase internal and inter-religious harmony.

Then, because religious harmony is an important part of national harmony, then the regions, in order to implement autonomy, have the obligation to carry out the obligatory affairs in the fields of planning, utilization, and supervision of spatial as well as the obligation to protect the public, maintain unity, entity, and national harmony as well as the wholeness of the country. Thus, regional heads and regional deputy heads, in order to carry out their duties and authorities, have the obligation to maintain peace and order in society.

But in its development, PBM 2006 is considered unable to answer the problems of religious harmony in Indonesia (Patty, 2007). PBM 2006 is considered by some to be one of government policy that, throughout the implementation, has not been going as well as expected, and in some cases, the regulating is discriminative (The Indonesian Institute / TII, 2015). From the aspect of the implementation of regional heads' tasks, as the authority of the government at the local level, regional heads often do not perform the function of his service in a non-discriminatory manner. From the aspect of the implementation of the Forum for Religious Harmony (FKUB) empowerment function, regional leaders (in this case regional deputy heads) as the counselor in FKUB are not functioning properly. If they do function, it is more to appeal to the masses for political interests only.

From the aspect of the implementation of the establishment of a house of worship, especially the issues related to the requirements for the establishment of a house of worship. In the case of the establishment of a house of worship, often time regional heads, in doing their service, are still discriminative. With PBM 2006, just makes it more difficult for the religious community to get their house of worship as it relates to the issue of requirements for the establishment of a house of worship. The conflict continues to occur because of the issue of the establishment of a house of worship. The difficulty in establishing a house of worship almost happened to all the religions in Indonesia. The rejection of the construction of houses of worship can cause conflicts that could disturb religious harmony, tranquility, and public order.

Actually, the issue of religious harmony has been studied. For example, Wahid (2005) examined the idea of harmony between religious community in Indonesia, Hamdi (2013) examined the management policy of diversity with the case study of the Joint Regulation of the Minister of Religious Affairs and the Minister of Home Affairs No. 8 and 9 of 2006 on guidelines for Regional Head in the management of Religious Harmony, formation of FKUB, and the establishment of houses of worship, Keewuel (2013) examined the nature of religion (its contribution to dialogue and harmony between religious communities in Indonesia), Sukarjiman (2008) examined the harmony between religious communities in the context of national security, and Lonto (2001) examined the role of religious elites in fostering inter-religious harmony in the municipality of Manado. All these studies basically revealed that religious harmony in Indonesia is still not in accordance with what is expected (there are still many problems facing the government in creating religious harmony).

The study results earlier on the evaluation of PBM 2006 was also carried out by the Indonesian Institute / TII (2015), which among other things found a few things, namely the lack of multicultural education in the community, no clear program of work and activities of FKUB, weak recruitment of FKUB, as well as the different view between local government and the administrators of FKUB about PBM 2006. The point is, the implementation of PBM in 2006 is felt less effective and require an increase in its legal status to become a Law. This study is similar to the TII study, but this study is more specific and focuses on a 1 (one) region alone, namely East Java Province.

In addition, the implementation of PBM 2006 has not been running as well as expected because it is hampered by the weak role of the actors in implementing this regulation, weak socialization of PBM 2006, weak law enforcement, lack of multicultural education in the community, and so on (Suryana, 2011).

Specifically in East Java Province, the leaders of the Communication Forum for Religious Community in East Java stated that there are several issues that become the source of conflict in the implementation 
of the development of religious harmony, but what often becomes severe is related to the establishment or existence of house of worship in East Java Province (Kompas.com, 2015). For example, the action in Tolikara, Papua directly impact the tightening of security of non-Muslim houses of worship in a number of regions, including in Surabaya. Some churches in the capital city of East Java seemed guarded by police officers on Sunday (19/07/2015), such as Jemaat Mapan Indonesia Bethany Church in the area of East Surabaya (Kabar24.Com, 2015).

Based on the description above, it is necessary to evaluate the existence of PBM 2006, both in terms of implementation and in terms of regulation (the regulation content). This is important as the management effort of religious harmony in order to maintain national unity.

The main problem in this study is the implementation of the Joint Regulation of the Minister of Religious Affairs and the Minister of Home Affairs No. 9 and No. 8 of 2006 (PBM 2006) that is assessed by many people has not run well and also discriminatory. The formulation of the problem in this study relates to the subject matter are: (1) How is the implementation of the tasks of regional heads in maintaining religious harmony? (Services, setting, and empowerment of religious communities); (2) How is the implementation of the function of religious harmony empowerment forum?; (3) How is the implementation of the establishment of the house of worship, granting a temporary permit for the utilization of building, and dispute resolution?; (4) What factors are inhibiting the implementation Joint Regulation of the Minister of Religious Affairs and the Minister of Home Affairs No. 9 and No. 8 of 2006 (PBM 2006)?; and (5) What policies should be taken to further streamline the implementation of the tasks of regional head/regional deputy head in the maintaining religious harmony, empowerment of FKUB, and the establishment of house of worship?

The purpose of this study is to provide a factual description of the implementation of the Joint Regulation of the Minister of Religious Affairs and the Minister of Home Affairs No. 9 and No. 8 of 2006 (PBM 2006). The objectives of this study are: (1) Determining the implementation of the tasks of regional heads in maintaining religious harmony (services, settings, and empowerment of religious communities); (2) Knowing the implementation of the empowerment function of religious harmony forum; (3) Knowing the implementation of the establishment of house of worship, granting a temporary permit for the utilization of building, and dispute resolution; (4) Identify the factors that hinder the implementation of the Joint Regulation of the Minister of Religious Affairs and the Minister of Home Affairs No. 9 and No. 8 of 2006 (PBM 2006); and (5) Recommending the policies that need to be taken to further streamline the implementation of the tasks of regional head/regional deputy head in the maintaining religious harmony, the empowerment of FKUB, and the establishment of house of worship.

Furthermore, based on the descriptions above, the flow of thought in this study can be described as follows:

\section{METHOD}

This study is conducted in East Java province. The choosing of the location (arena) is done intentionally (purposive), with the consideration that East Java Province is one of the provinces in Indonesia that implement the regulation of PBM 2006, so it should be evaluated the implementation of the regulation of PBM 2006 in the region. The study uses naturalistic or qualitative methods descriptive explanation. According to Whitney (2000), descriptive research or study is fact finding with the correct interpretation. Descriptive explanation of this study is to make a description or illustration of systematic, factual, and accurate information on empirical facts relating to the implementation of the regulation of PBM 2006. Data collection in this study uses methods as follows: (1) documentation, (2) interviews, and (3) FGD. There are two (2) types of data collected, primary data and secondary data. The primary data obtained from interviews directly with the competent parties in the implementation of the regulation of PBM 2006. The secondary data obtained from the literature/documentation of studies and supporting data that are relevant to the current study sourced from related institutions in the implementation of the regulation of PBM 2006. In accordance with the method of data collection used above, the instrument (tool) of study or data collection tool used in the study are: (1) checklist/ document analysis, (2) guidelines for an open interview, and (3) guidelines for FGD. As for the informants in this study, they are the competent parties in the implementation of the regulation of PBM 2006, namely officials of the provincial ministry of religious affairs, officials of Kesbangpol Agency, FKUB, and officials from other relevant agencies. The types of data in this study are qualitative data and quantitative data. The method of processing and data analysis used is a descriptive method. Once the data is collected, it is then classified into two (2) groups of data, namely quantitative data and qualitative data. To the qualitative data, which is described by the words or phrases, is separated by category to obtain conclusions. As for quantitative data, it is in the form of tangible figures processed with calculation, add up, or percentage, and then described. Furthermore, to address problems that have been formulated before used some theoretical reference. First, the Religious Harmony. 
Harmony can be interpreted as a condition of life and life that reflects the atmosphere of peaceful, orderly, prosperous, respect, appreciation of one another, tolerance, and mutual cooperation in accordance with religious teachings and personality of Pancasila (Jamzuri, 2013). Inter-religious harmony can be regarded as a social condition in which all religious groups could coexist together without compromising the fundamental rights of the people to perform their religious duties (Jamzuhi, 2013). The inter-religious harmony stated is to strive for the creation of a state where there is no conflict internally within the respective religious communities, inter-denominations that differ from one another, between the followers of a religion with the followers of other religions, between the followers of religions with the government (Suryana, 2011; Gunaryo, 2012).

Second, the concept of Tri Harmony. Indonesia is based on Tri religious harmony that aims to make the Indonesian people can live in unity, even though many differences (Yewangoe, 2012; Laluyan, 2010). Tri Harmony includes three harmonies, namely: (1) internal harmony within the religious community, (2) inter-religious harmony between religious communities, and (3) harmony between religious communities and the government (Munawar, 2005; Naim, 2003). Another inter-religious harmony, which is a form of harmony that exists between people who embrace different religions. For example, the harmony between Muslims and Christians, between the Christian and Buddhist, or harmony performed by all religions (Abdullah, 2001; Ghazali, 2004).

Third, the overview of Joint Regulation of the Minister of Religious Affairs and the Minister of Home Affairs No. 9 and No. 8 of 2006 (PBM 2006). The release of this regulation is a form of government intervention in order to establish religious harmony that has confidence, and different Shari'ah, and the technical guidelines for regional heads/regional deputy heads in the context of maintaining of religious harmony. The Joint Regulation of the Ministers issued is a regulatory policy (beleidsregel) with a function to perform the duties of government that must not conflict with laws and regulations, and are not binding in general, and the Joint Regulation of the Minister does not conflict with the Constitution and Human Rights (HAM) ( Patty, 2007; Thantowi 2006; Cotteral, 2006).

The Joint Regulation of the Minister 2006, as a product of laws made by the ministers, then the regulation is the responsibility of the government as a party that issued it. As a product of law as well as public policy, certainly it always brings up the pros and cons (Soemarwi, 2006). Then, it is no wonder if there are parties and some members of DPR who disagree and oppose the regulation because it will give birth to fragmentation and discrimination from
PBM 2006 (Kompas, 2006).

Regardless of the pros and cons, the PBM No. 9 and No. 8 of 2006, which consists of 10 Chapters and 31 Articles, in substance has some crucial points that should be and need to be made into government regulation, or presidential regulation, or Law.

1. The maintaining of Religious Harmony. Religious community and the government should make a joint effort to maintain religious harmony in the field of service, regulating, and empowerment of religious communities. Maintaining of religious harmony in the province is the duty and obligation of the governor who is assisted by the head of the regional office of the provincial religious affairs. As for District/City, it is the responsibility of regents/mayors, assisted by district/city religious department office. (Perwiranegara, 2009). The scope of peace and order, including facilitating the establishment of religious harmony, coordinating the activities of Government agencies, fostering harmony, mutual understanding, mutual respect, and mutual trust among religious communities.

2. The empowerment of Forum for Religious Harmony. The birth of the Forum for Religious Harmony (FKUB) as a communication forum of religious leaders in order to maintain harmony among each. This forum requires an element of many religious elements the balanced position (Razi, 2007). The composition is determined according to the Joint Regulation, the members of the provincial Forum for Religious Harmony (FKUB) are 21 people, and the members of District/City are 17 people consisting of local religious leaders, in accordance with article 10. The active role of FKUB is really decisive in determining the creation of harmony and avoidance of conflict or dispute.

3. The establishment of a house of worship. Establishing a house of worship is the rights of every religious community (Ismail, 2011). In accordance with the joint regulation of two Ministers in Article 13 on the establishment of house of worship, this is based on real need and truly based on the composition of the population for the service of religious communities concerned in the territory of the urban-village/village, done while maintaining religious harmony, unobtrusive to peace and public order, as well as comply with the legislation. The requirements of establishing house of worship include a list of names and identity card (KTP) of the users of the house of worship, at least 90 people, which is approved by the local authorities in accordance with the level of boundaries, should have the support of local communities of at least 60 people 
and approved by urban-village head/ village head, written recommendation from the head of religious affairs department office of the district/city as well as written recommendation from the Forum for religious Harmony (FKUB) in district/city (PBM 2006 Chapter IV, 2006).

4. Temporary Permit for Building Utilization. Building Utilization of a building that is used for a house of worship must obtain a temporary permit from regents/mayors, with the requirements of proper functioning, namely preserving religious harmony and public peace and order (Hasani, 2011). With prior written permission from the owner of the building, written recommendations from urban-village/ village heads, written report to the Forum for Religious Harmony (FKUB) in district/city, and written report to the head of the religious department office in district/city.

5. Dispute resolution. Dispute resolution as referred to in the Joint Regulation is limited to dispute of the establishment of a house of worship. What if there is a dispute related to beliefs and religious broadcasting? Whatever the problems is, as long as they are related to religious conflict, then FKUB plays a central and pivotal role in resolving the conflict and religious issues (Wulandari, 2012).

Fourth, Aspects of Implementation PBM 2006.

Referring to the substance of the PBM 2006, can be known the aspects of the implementation of the regulation, namely:

1. Aspects of the implementation of the tasks of regional head (governor) in maintaining religious harmony (services, regulating, and empowerment of religious communities include: (a) Implementation of the maintenance of public peace and order, including facilitating the realization of religious harmony in the district / city; (b) Implementation of activities coordination of vertical institutions activities in the district in the maintenance of religious harmony; (c) Implementation of activities to build harmony, mutual understanding, mutual respect, and mutual trust among religious community; and (d) Implementation of activities in the promotion and coordination of sub-district heads, urban-village heads, or village heads in the administration of local governance in the field of public peace and order in religious life.

2. Aspect of the implementation of the empowerment functions of forum for religious harmony (at provincial level) including: (a) Implementation of dialogue with religious and community leaders; (B) Implementation of shelters for the aspiration of religious organizations and aspirations of community;
(C) Implementation of the distribution of aspirations of _ religious organizations and the community in the form of recommendations as the material of the regent's policy; and (d) Implementation of socialization activities of legislation and policy in religious matters related to religious harmony and community empowerment.

3. Aspect of the implementation of the establishment of house of worship, the granting of temporary permit of the building utilization, and dispute resolution including: The implementation of the fulfillment of the administrative requirements of establishment of house of worship; (b) The fulfillment of technical requirements of the establishment of house of worship; (c) The implementation of the fulfillment of specific requirements in the establishment of house of worship; (d) The implementation of the requirements fulfillment of temporary permit granting of the utilization of building; and (e) The implementation of dispute settlement.

\section{RESULT AND DISCUSSION}

\section{A. Description of Study Location}

The population of East Java province in 2014 amounted to 37,476,757 inhabitants, and the largest population in the province is located in the city of Surabaya. The province consists of 29 districts and 9 cities. In East Java province, Muslim is majority $(36,113,396$ inhabitants of the total population of $37,476,757$ inhabitants, $96.36 \%$ ), followed by Christian population as much as 638,476 inhabitants, Catholics as much as 234,204 people, Hindu as many as 112,177 people, Buddhism as many as 60,760 people, and the Confucianism as many as 9,166 people.

The number of religious organizations in East Java province in 2012 is 38, while in 2013 was 37, and in the year 2014 is 38 organizations. Religious organizations include organizations of Islam, Christianity, Protestantism, Budha, Hinduism, and Confucianism. Meanwhile, the biggest number of houses of worship in East Java is the Mosque (1224 units), then followed consecutively by the church (447 units), the monastery (26 units), Temple (11 units), and the temple (6 units). In 2014-2015, in East Java Province, recorded the number of IMB for the mosque is 10 , for the church is 5 , and to the monastery is 2 .

\section{B. The Implementation of Regional Head (Governor)'s Duties in Maintaining Religious Harmony in East Java Province} In the implementation of public peace and 
order maintenance, including facilitating the realization of religious harmony in the district / city, East Java Governor made a Decree No. 188/43/ KPTS/013/2011 on the Advisory Board of FKUB. Its job is: (a) assisting the Governor of East Java in formulating policies of maintaining religious harmony; (B) facilitating the working relationship of Forum for Religious Harmony (FKUB) with the Government of District/City in East Java and relationship between the relevant agencies in the maintenance of religious harmony, with a budget that is charged to East Java provincial budget; (C) establishing a Secretariat as required; and (d) reporting the results of the implementation of the Governor of East Java's duties. Targets to be achieved is the fostering of conducive environment supported by harmonious coordination and cooperation between all parties that are functionally related, the fostering and maintaining of religious harmony in East Java.

In addition, East Java Governor is assisted by the head of the regional office of the provincial ministry of religious affairs to supervise the regent/ mayor and relevant agencies in the region on the implementation of the maintaining of religious harmony, the empowerment of forum for religious harmony, and the establishment of a house of worship. Furthermore, the Governor of East Java reports the implementation of the maintaining of religious harmony, the empowerment of forum for religious harmony, and the regulating of the establishment of house of worship in the province to the Minister of Home Affairs and the Minister of Religious Affairs with cc to the Coordinating Minister for Political, Legal and Security and the Coordinating Minister of Public Welfare. The report shall be submitted every 6 (six) months in January and July, or at any time if deemed necessary.

The problem faced is the report on the implementation of the tasks of Advisory Board of FKUB which is often too late so that the East Java Governor also delays the formulation of more specific policy in maintaining religious harmony, including religious anticipating the problems that occur in the field. In addition, the facilitation budget is inadequate so that the Advisory Board of FKUB is difficult to optimize the performance of its duties, primarily for the purpose of facilitation. For example, the lack of supporting facility the implementation of activities, especially when visiting the district/city in the scope of the organization's work area.

Another problem is the frequent late report from East Java Governor to the Minister of Home Affairs and the Minister of Religious Affairs, regarding the monitoring activities by the head of the regional office of the provincial ministry of religion to regents/mayors and relevant agencies in the regions that experience constraints on lack of facilitation fund to make a visit to the regions. In the implementation of the coordination of activities of vertical agencies in the province in the maintenance of religious harmony, East Java Governor instructed the Government agencies in order to improve the external coordination, with authorities, religious councils, organizations of religious organizations, and other concerned parties in order to develop and maintenance religious harmony (KUB) in East Java province.

The problem faced is often on the religious mass organizations that do not do prior coordination with vertical agencies before conducting their activities, or there is coordination, but there is different perception so that in practice, this often dissatisfies some parties.

In the implementation of the activities of growing harmony, mutual understanding, mutual respect, and mutual trust among followers of religions, the Governor of East Java in any religious gatherings always asks all the components involved to always improve understanding and mutual understanding, and encourage the participation and cooperation of religious community in strengthening the foundations of religious harmony in order to build and maintain social harmony in East Java Province, including within the framework of national unity and integrity. Target to be achieved is the creation of an atmosphere of religious life that is conducive to the understanding, appreciation and practice of the teachings of religion and the growth of mutual understanding, participation and cooperation of the religious community, which support the development and maintenance of religious harmony.

The problem faced is the lack of commitment of most of the components involved in religion in performing its role in maintaining religious harmony in East Java Province. This happens especially when the interest or perception is different in addressing religious issues in East Java Province.

In the implementation of the activities of development and coordinating of regent/ deputy regent and mayor/deputy mayor in the administration of local governance in the field of public peace and order in religious life, coaching, and coordination done by the Governor of East Java is to instruct regent/deputy regent and mayor/deputy mayor in order to implement, develop, coordinate, and also report the results of the religious programs and activities that have been set by the government of East Java Province.

Programs and activities are: (1) Consolidation of Internal Affairs (composing the institutional management of FKUB and constructing a system of administrative services); (2) Consolidation of External Affairs (Achieving coordination and cooperation between related elements and creating 
a conducive atmosphere); (3) Harmony Maintaining Affairs (Multiplying and distributing PBM 2006; collaborating with religious leaders in order to socialize legislation especially in relationships among religious community up to the lowest layer/ grass root; in collaboration with religious leaders in order to improve understanding and practice of religious teachings; to explore and develop the potential of a positive local wisdom to support religious affairs; compose pets prone to religious conflicts in East Java; and disseminate messages of religious affairs through billboards media); (4) FKUB Empowerment Affairs (Holding consolidation on the management of FKUB in District / City in accordance with PBM 2006; collating database about the potential and activity of FKUB; compiling directory of FKUB in District/City and publishing bulletin of FKUB; conducting seminars, workshops, meetings and inter-religious dialogue in order to improve insights into harmony to the board of FKUB, cadres of religious harmony, and religious communities; building a network/net-working with other religious harmony institutions; and conducting evaluation on Annual Work-Shop with FKUB in District/City); and (5) Establishment of House of Worship Affairs (Socializing legislation related to the establishment of house of worship; conducting cooperation with relevant institutions and religious institutions in order to facilitate the establishment of house of worship; conducting guidance and supervision to the process of establishment of house of worship; and building cooperation with all parties in order to create favorable conditions at the district/city, among others, through early detection of the likelihood of conflict and seek a comprehensive solution).

The problem faced is that there are still plenty of the regents or mayors who still rely on the implementation of programs and religious activities by FKUB. That is, the FKUB is expected to be proactive while other related components just have to monitor only. Such conditions can hamper the success of the programs and activities that have been declared by the Governor of East Java.

\section{The Implementation of Empowerment Function of the Forum for Religious Harmony in East Java Province}

In the implementation of dialogue activities with religious and community leaders, the implementation of the dialogue activities with religious and community leaders in East Java Province always involves the related parties to the maintenance of religious harmony in East Java.

The problem faced is that often not all religious leaders and community leaders are invited and present in a religious dialogue organized by FKUB of East Java. Consequently, what is produced from a dialog is often not appropriate or is not satisfactory to certain parties, especially those who are not present in the dialogue. This caused some people to protest against religious policy formulated by the government of East Java Province, especially the policy of the establishment of a house of worship.

In the implementation of the activities of religious organizations aspiration and community aspiration shelter, the activities of sheltering of religious mass organizations aspiration which first accommodated by their respective religious organizations in East Java province, either written aspiration or aspiration through dialogue results (orally). The aspirations of the public generally beforehand accommodated in each RW / RT. The aspirations are then recorded and submitted to FKUB by mail.

The problem faced is the aspirations accumulated are quite a lot and of course based on the interests of each aspirator, so as sometimes contradictory between one religion to another religion. This certainly causes a long debate, and sometimes consensus is not achieved in resolving problems at the level of FKUB. Moreover, one of the problems of the recruitment of FKUB members is that the composition of FKUB membership is based on a comparison of the number of religions, which allows the domination of the majority.

In the implementation of distribution of religious organizations and the community aspirations in the form of recommendations as the governor's policy, generally, the channeling of religious organizations and communities' aspirations to FKUB is already in the form of policy recommendations for the governor. However, in order for the aspirations to be directed and focused, FKUB reinvite the aspirators to have a dialogue in reformulating the recommendations to be submitted to the Governor of East Java.

The problem faced is that often time, consensus on recommendations to be submitted to the Governor is not achieved. Consequently, the recommendations made normally will not address the problems encountered in the field. In addition, often happens mismatch of understanding between local government and FKUB, so there are some aspirations that are not followed up in the policy of the Governor.

In the implementation of the socialization of legislation and policy in religious matters related to religious harmony and community empowerment, the citizens of East Java are still lacking in the socialization of PBM 2006 which led to the inequality of view to the implementation of PBM 2006, mainly to the implementation of the policy of the establishment of house of worship as well as policy in granting a temporary permit for the utilization of building for worship. Ideally, people 
should continue to be given an explanation so that they can better understand the intent and purpose of government policy.

\section{The Implementation of the Establishment of Houses of Worship, Granting of Temporary Permit for the Utilization of Building, and Dispute Settlement in East Java Province}

In the implementation of compliance with the administrative requirements on the establishment of a house of worship, and administrative requirements of the establishment of a house of worship are the certificate of land ownership and others. The fulfillment of the requirement is not disputed by East Java Province community. The local communities remain subject to the conditions set by the government.

In the implementation of compliance with the technical requirements of the establishment of a house of worship building, the technical requirements of the establishment of the house of worship building are like the requirements of the building layout. This layout requirement has been stipulated in Law No. 28 of 2002 on Building. The fulfillment of technical requirements is also not disputed the community of East Java Province. The local communities remain subject and follow the conditions set by the government.

In the implementation of compliance with the special requirements of the establishment of house of worship, the establishment of houses of worship must meet special requirements including: (a) a list of the names and National Identity Card of the users of house of worship at least 90 people legalized by the local authorities in accordance with the boundaries level as referred to in Article 13 paragraph (3); (b) support local communities of at least 60 people legalized by the urban-village head/ village head; (c) a written recommendation from the head of religious department office in district/ city; and (d) a written recommendation from FKUB in district / city.

In case the condition (a) above is met, while the condition of (b) above has not been met, the local government is obliged to facilitate the availability of the establishment site of the house of worship. For FKUB recommendation (letter $\mathrm{d}$ above) is the result of discussion and consensus in FKUB meetings, poured in written form. Request for the establishment of a house of worship is filed by the house of worship building committee to the regent/ mayor to obtain a house of worship building permit. Regent/mayor to issue a decision no later than 90 (ninety) days since the request for the establishment of a house of worship is filed. The local government facilitates the provision of new locations for the establishment of the house of worship which has had Building Permit being moved due to changes in spatial plans.

Fulfillment of the specific requirements is what being complained by minority religion followers. The requirements for the establishment of a house of worship as set forth in the Joint Decree (SKB) of The Minister of Home Affairs and the Minister of Religious Affairs needs to be revised. Especially, the conditions associated with the liabilities to gain approval of 90 people in the surrounding where the house of worship will be established. It should be considered to be reduced. If needed, to be abolished.

Governments have an obligation to facilitate people who want to build a house of worship in accordance with their respective belief. The existence of Joint Decree which regulates the requirements for establishing lest it causes conflicts between religious communities. To establish a house of worship, what should be considered is the ownership of the building permit. Therefore, it needs to be coordinated with the Minister of Religious Affairs Minister and Coordinating Minister for Political, Legal, and Security to discuss this. After that then reported to the cabinet meeting. Minister of Religious Affairs must take the initiative to hold a meeting to establish religious harmony.

In the implementation of compliance to the requirements of temporary permit for the utilization of building, the utilization of building, which is not intended as house of worship, as a temporary house of worship should receive a certificate on the granting of temporary permit from regents/mayors by meeting the following requirements: (a) eligible functions; and (b) the maintenance of religious harmony as well as public peace and order.

The requirement of an eligible function refers to the legislation on buildings. The requirements on the maintaining of religious harmony and peace and public order including: (a) written permission of the building owner; (b) written recommendation of urban-village head/village head; (c) written report to the FKUB in district/city; and (d) written report to the head of the religious department office in district/city.

The certificate on the granting of the temporary permit of the utilization of building not intended as a house of worship by the regent/mayor is issued after considering the written opinion of the head of the religious department office in district/city and FKUB in district/city. The certificate on the granting of the temporary permit of the utilization of building a house of worship is valid for a maximum period of 2 (two) years. The issuance of a certificate on the granting of the temporary permit is delegated to the sub-district head. The issuance of a certificate on the granting of the temporary permit is conducted after considering the written opinion of the head of the religious department office in district/city and 
FKUB in district/city.

The fulfillment of the above requirements is also assessed by the religious community of minority religions to be burdensome. In certain situation, religious people also need a place of worship as an integral part of religious and belief. In the case of certain religious communities do not have the ability to build a house of worship, religious communities are entitled to utilize a building or part of the building as a place of worship. The licensing procedure for the use of places of worship should be congruent with the spirit of the 1945 Constitution which guarantees freedom of religion/belief. Licensing the use of places of worship should not become an instrument of discrimination through administrative procedures.

In the implementation of religious dispute settlement, disputes due to the establishment of a house of worship are settled amicably by the local community. In the case of consensus is not reached, the dispute settlement is conducted by regent/ mayor assisted by the head office of religious affairs ministry of district/city through consultation conducted fairly and impartially to consider the opinions or suggestions of FKUB in the district/ city. In case the dispute settlement is not reached, then the dispute settlement is conducted through the local courts. East Java Governor implements guidance to regents/mayors and related institutions in the region to resolve disputes.

In resolving conflicts on the establishment of a house of worship that occurred in East Java Province, the first thing that must be performed by FKUB is to conduct an evaluation/examination on the application for Building Permit is addressed wisely, then FKUB provides the illustration of Law that govern the Establishment of House of Worship.

After that, FKUB conducts discussions to discuss and resolve problems that occur, but the absence of pro-active from the builder of the church who did not attend the meetings conducted by FKUB. The discussion is continued up to many times with everything related to the establishment and government officials who carried out wisely and according to rules to address problems that occur.

Forum for Religious Harmony (FKUB) also applies problem-solving approach where there is a problem, then there will be solution conducted without the use of violence or acts of anarchy. Due to the anarchic action, the problem will not be finished with the word peace.

Forum for Religious Harmony (FKUB) always accommodate the aspirations of religious organizations, especially in terms of the establishment of a house of worship. Indeed, minority communities must understand the situation and the conditions in the surrounding areas because the rules on the establishment of houses of worship have been arranged in which the decision is already set in the discussion of religious leaders across Indonesia that has been constituted and recognized by the respective religious followers.

Forum for Religious Harmony (FKUB) the resolution of conflicts for the establishment of a house of worship in Mulung Village, through stages, namely with peacemaking and peacebuilding. In terms of peacemaking, FKUB is presented as a third party who has a role as an arbiter of warring factions among the builders of the church and the people, but FKUB does not have the rights to determine the decisions taken, because it is not the territory of FKUB but the government officials of districts/ cities supported by government officials of East Java Province. FKUB also only mediate in the event if the atmosphere heats up between the warring parties (builder of churches and community) who are negotiating with government officials from the government, either from District/City and the Province.

FKUB also performs peacebuilding, where FKUB give suggestions that can still unite the warring parties (builder of the church, community, and government officials) regardless of SARA and government. Because it clearly defined the functions and duties of the establishment of FKUB, simply and solely to keep, maintain, and streamline interreligious harmony, so no grudge imprinted on the warring parties.

The case of the establishment of a house of worship, the focus of attention used is to give an explanation to the problems that led to conflict, to discover the principles of the process and policies derived from an explanation of the conflict. Here, the party that establishes the church, FKUB members, and government officials from the district to the provincial verify the occurrence of this conflict and listen to various parties about the occurrence of these cases, which eventually the decision-making conducted by the government officials more eligible regardless of SARA. Because conflicts can occur for other religions that will build a house of worship.

The conflict there including realistic conflict, because the real conflict is not getting construction permit but still establish a house of worship without thinking and scrutinizing all proposed requirements prior to the construction of a house of worship. There is lots time, energy and thoughts devoted to resolving the conflict. So it must be done with repeated discussion with the existence of conflicts on the establishment of a house of worship.

From the case of the establishment of a house of worship, of course, there is a feeling that this is unfair to them since there is legislation on their religious freedom. Therefore, there are many minority communities who will struggle to get a house of worship, because the house of worship is 
a means used to worship to the Divine. However, all the existing rules of freedom, if not regulated will cause discomfort among one another.

\section{E. Factors that Hinder the Implementation of Joint Regulation of the Minister of Religious Affairs and the Minister of Home Affairs No. 9 and No. 8 of 2006 (PBM 2006) In East Java Province}

There are at least four (4) main factors that hinder the implementation of the PBM 2006 in East Java Province over the years. First, the commitment factor. The still weak role of actors in implementing the regulation in East Java Province. Some local governments in East Java are considered having no political will in implementing PBM 2006. In fact, most of the regional heads consider PBM 2006 program is not part of the main priorities of the regional heads. In addition, there are still regional heads who can not do justice if it is faced with mass pressure on conflict related to house of worship establishment. Often in their duties, Regional Heads are challenged by intolerant groups. These groups often urge the heads of the region not to give permission to the establishment of a house of worship to minorities. In fact, as the authorized government at the local level, Regional Head should have been able to run the service function in a nondiscriminatory manner.

In addition, happened a mismatch of understanding between local governments and officials of FKUB about PBM 2006. Similarly, the formation of FKUB is considered just a formality. This is because the regional leaders (in this case the regional deputy head) as a counselor in FKUB is not functioning properly. If he does function, it is only to appeal to the masses for the sake of political interest. Another thing is the recruitment of FKUB members. One of the problems of the recruitment of FKUB members is that the FKUB membership composition is based on a comparison of the number of religions, which allow the domination of the majority. Another condition is unclear work program and activities of parts of FKUB. FKUB activities are more to visit/ study abroad and to the regions but do not address the problems that exist in the region itself.

Second, Socialization Factor. The weak socialization of PBM 2006 in East Java Province causes mismatch of understanding between the central government and local governments about the substance PBM 2006; the duties and authority of regional heads; the role and empowerment of FKUB; the implementation of the requirements for establishing house of worship to the resolution of conflicts arising from the establishment of house of worship, including the issue of socialization in East Java province regions are the problem of the lack of fund for socialization.
Lack of socialization also further strengthen the influence of community leaders at the local level that is still strong enough to reject the establishment of a house of worship of minority religions, especially supported by specific requirements on the establishment of a house of worship that seem discriminatory.

Third, Law Enforcement factor. The weak law enforcement is because PBM 2006 does not have a strong legal force and binding, and the absence of a strong attitude of the regional heads to enforce the law. The local government in East Java province is subject when dealing with the pressure of the masses so that the law is controlled by the pressure of the masses.

Fourth, the Community Education Factor. Weak multicultural education in East Java Province due to lack of multicultural education in society, including the lack of knowledge of comparative religions, so that people do not know each other's religions. Both of these things caused blind fanaticism in some communities that are based on the lack of knowledge so that the diversity of this nation is threatened.

\section{F. The Policy that needs to be taken to Further Streamline the Implementation of the Tasks of Regional Head/Regional Deputy Head in the Maintaining Religious Harmony, the Empowerment of FKUM, and the Establishment of House of Worship in East Java Province}

Based on the description of the factual description above regarding the implementation of the tasks of regional head (governor) in maintaining religious harmony, the implementation of the functions of empowerment of forum for religious harmony, the implementation of the establishment of house of worship, the granting of temporary permit for building utilization, and dispute resolution, as well as factors that hinder the implementation of Joint Regulation of the Minister of Religious Affairs and the Minister of Home Affairs No. 9 and No. 8 of 2006 in East Java Province, then the policy that needs to be taken to further streamline the implementation of the tasks of regional head/ regional deputy head in the maintaining of religious harmony, the empowerment of FKUM, and the establishment of house of worship in East Java province.

First, the implementation of the tasks of regional head/regional deputy heads in the maintaining religious harmony, the empowerment of FKUM, and the establishment of the house of worship is not considered effective if it is based on a legal framework of PBM 2006. Therefore, the policy that needs to be realized is to develop 
PBM 2006 to be a Law. In connection with this, it is necessary to speed up ratification of the Bill for Religious Protection (PUB). The implementation of PBM 2006 is felt less effective, required increased legal status to become Law. Religious Protection Bill that is initiated by the government is expected to answer the problems that developed at this time, where now there are still discrimination and lack of protection of minorities. The Bill is expected to provide a certain legal framework for both central and local governments to prevent and crack down firmly conflicts with a religious background.

Second, related to the function of local Development and Supervision (Binwas) by the Ministry of Home Affairs, including the fostering of religious in the regions, then the Ministry of Home Affairs needs to help drive the acceleration of the legalization of the PUB Bill and continue to coordinate with the Ministry of Religious Affairs, including actively involved in the process of drafting the PUB Bill in order to provide input for the improvement of PUB Bill. The Ministry of Home Affairs needs to discuss it first in the level meeting of the Coordinating Minister for Politics, Law, and Security and the Minister of Religious Affairs. After that, the meeting is reported in a cabinet meeting. In this regard, the Minister of Religious Affairs should take the initiative to hold or form a meeting to build religious harmony. The Ministry of Home Affairs through the Directorate General of Politics and General Administration also needs to coordinate with relevant agencies and provide input to the PUB Bill after leveling the perception with the Minister of Religious Affairs, the Attorney General, the Minister of Law and Human Rights, as well as coordinating with ministries under the Coordinating Minister for Politics, Law, and Security.

Third, prior to the ratification and enforcement of the Law of PUB, currently the apparatus of Directorate General of Politics and Polpum and the Directorate General of Regional Autonomy of the Ministry of Home Affairs better provide explanation to the regional heads of provinces, districts/cities related to local regulation to the establishment of house of worship. The local regulation of the establishment of a house of worship must be consistent and firm with regulations and licensing process. In principle, the local government facilitates the people so they can feel safe to build a house of worship. In addition, the Directorate General of Politics and Polpum and the Directorate General of Regional Autonomy of the Ministry of Home Affairs need to continue to coordinate with the police to crack down the riots that disrupt the solemnity of worship for every citizen. The government must be present in the midst of people who feel disturbed in conducting worship and the construction of a house of worship. Religious tolerance must continue to be built and resuscitated. To anyone who disturb or provoke must be dealt with firmly by the police.

Fourth, the Ministry of Internal Affairs should immediately circulate a letter to all district heads to form FKUB at the district level. Therefore, the sub-district is the region's leading coordinator of village/urban-village government. If the subdistrict head and the partners, Danramil and police chief, have good sensitivity and early detection capability, they will be able to prevent conflicts in the regions. According to Law Number 23 Year 2014 on Regional Government, the sub-district head needs to coordinate with the military (TNI) and police (Polri), including urban-village heads and village heads. The district head also needs to establish communication with religious leaders, traditional leaders, and all level of society. It is a must to build strong interaction between local government and its society in order to avoid misunderstanding or miscommunication that could lead to religious conflict.

Fifth, things that need to be emphasized on the PUB Bill, especially:

1. In the PUB Bill, it should be emphasized on law enforcement arrangements in accordance with the principles of fairness, diversity, and equality. Law enforcement is aimed at anyone who commits an offense, regardless of religion and belief. The firmness against intolerant groups which commit violence in the name of religion.

2. The affirmation of socialization in the PUB Law up to the structure of lower level (the level of RT and RW), so that people can understand the PUB Law. Socialization is indispensable to be passivated to the lowest local government officials such as urban-Village/Village, District, as well as law enforcement officials (such as police and prosecutors) that later shared joint understanding with PUB Law. Similarly, it is to be stressed out that the Government should establish an effective socialization method to so that message (in this case the content of PUB Law) is delivered on target.

3. In the bill of PUB, also need to be contained the passivating of multicultural education. Education that respects and upholds the diversity of cultures, ethnicities, races, and religions. Such respect and appreciation is the attitude that urgently need to be socialized to the community, especially the younger generation.

4. To avoid mismatch of understanding between central government and local governments regarding the substance of the rules, duties and authority of regional heads, the role and empowerment of FKUB, the implementation of the requirements for the establishment 
of house of worship until the resolution of conflicts arising from the establishment of house of worship, then in the Bill of PUB, such matters are governed clearly, firmly, and non-discriminatory (do not cause multiple interpretations).

\section{Conclusion}

In general, the implementation of the tasks of the regional head (Governor of East Java Province) in maintaining religious harmony has not been effective. East Java Governor is yet to formulate a policy of maintaining of religious harmony quickly and more specific, so it cannot address the problems encountered in the field. The implementation of control activities by the heads of regional offices of the provincial ministry of religion towards regents/ mayors and related institutions in the region is weak. In addition, there are many regents or mayors who rely on the implementation of programs and religious activities by FKUB. This condition hampers the implementation of the program and the maintaining of religious harmony which has been declared by the Governor of East Java thus far. In addition, the implementation of the empowerment function of FKUB in East Java province has not been effective. The result of the dialogue conducted FKUB is often not appropriate or does not satisfy many parties, especially the policy for the establishment of a house of worship. For the implementation of the establishment of a house of worship in East Java Province, the fulfillment of specific requirements is complained by minority faiths. The requirements related the liability to gain the approval of 90 people in the region of the house of worship establishment should be considered to be reduced. As for the factors that hinder the implementation of the Joint Regulation of the Minister of Religious Affairs and the Minister of Home Affairs No. 9 and No. 8 of 2006 (PBM 2006) in East Java Province are: factor of lack of commitment of the implementers of PBM 2006, factor of lack the lack of PBM 2006 socialization, factor of weak law enforcement; and factor of the weakness of multicultural education in East Java province.

Things that need to be implemented by the Provincial Government of East Java are: to be committed to implementing PBM 2006 regulation, to socialize PBM 2006, strict law enforcement against those who violate the regulations, and to implement multicultural education in the local community.

\section{REFERENCES}

Abdullah, M. (2001). Pluralisme Agama dan Kerukunan dalam Keagamaan. Jakarta: Buku Kompas.

Cotteral, R. (2006). The Sociology of Law, An
Introduction. US: Prentice Hall.

Drs. H. Jamzuri: 3 Unsur Konsep Kerukunan Umat Beragama - Kantor Kemenag Kabupaten Karimun. (2013). Kemenagkarimun.blogspot. co.id. Retrieved 10 September 2013, from http://kemenagkarimun.blogspot. co.id/2013/09/drs-h-jamzuri-3-unsurkonsep-kerukunan.html

Ghazali, A. (2004). Agama dan Keberagamaan dalam Konteks Perbandingan Agama. Bandung: Pustaka Pelajar.

Gunaryo, A. (2012). Kebijakan Kementerian Agama dalam Pembinaan Kerukunan Umat. Antarasultra.com. Retrieved 23 May 2012, from http://www.antarasultra.com/ berita/264132/kebijakan-kementerianagama-dalam-pembinaan-kerukunan-umat

Hadi, S. (2005). Abdurrahman Wahid: Pemikiran tentang Kerukunan Antar Umat Beragama di Indonesia (Master Thesis). Universitas Muhammadiyah Surakarta.

Hamdy, M. (2013). Kebijakan Pengelolaan Keragaman Studi Kasus Peraturan Bersama Menteri Agama dan Menteri Dalam Negeri Nomor 8 dan 9 Tahun 2006 tentang Pedoman Bagi Kepala Daerah dalam Pengelolaan KUB, Pembentukan FKUB, dan Pendirian Sarana Ibadah (Dissertation). Universitas Gadjah Mada.

Hasani, I. (2011). Dokumen Kebijakan Penghapusan Diskriminasi Agama/Keyakinan. Jakarta: Pustaka Masyarakat Setara.

Herlinda, W. (2015). KASUS TOLIKARA: Antisipasi Konflik Susulan, Surabaya Tingkatkan Penjagaan / Kabar24 - Bisnis.com. Bisnis.com. Retrieved 19 July 2015, from http://kabar24. bisnis.com/read/20150719/15/454734/ kasus-tolikara-antisipasi-konflik-susulansurabaya-tingkatkan-penjagaan

Ismail, F. (2011). Pijar-pijar Islam: Pergumulan Kultur dan Struktur. Bandung: Tarsito.

Keewuel, H. (2013). Pemikiran Søren Kierkegaard tentang Hakikat Agama: Kontribusinya Bagi Dialog dan Kerukunan Hidup Antar Umat Beragama di Indonesia (Dissertation). Universitas Gadjah Mada.

Laluyan, J. (2010). Mendirikan Rumah Ibadah di Indonesia. Jakarta: Kemenag.

Lonto, L. (2001). Peran elite agama dalam membina kerukunan hidup antar umat beragama di Kotamadya Manado (Master Thesis). Universitas Gadjah Mada.

Ministry of Religious Affairs and Ministry of Home Affairs. (2006). Joint Regulation of the Minister of Religious Affairs and the Minister of Home Affairs No. 9 and No. 8 of 2006 on Guidelines for the Implementation Task Regional Head / Deputy Head of Maintenance of Religious Harmony In, Empowerment Forum for Religious 
Harmony, and the Construction of Houses of Worship. Jakarta: MInistry of Religious Affairs and Ministry of Home Affairs.

Munawar, S. (2005). Fikih Hubungan Antar Umat Beragama. Jakarta: Ciputat Press.

Naim, S. (2003). Kerukunan Antar Umat Beragama. Jakarta: Gunung Agung.

Patty, A. (2007). Menyikapi Peraturan Bersama Dua Menteri. Yogyakarta: Pustaka Pelajar.

Pendirian Rumah Ibadah, Sumber Konflik Kerukunan Umat Beragama - Kompas.com. (2009). KOMPAS.com. Retrieved 21 November 2015, from http://nasional.kompas.com/ read/2009/11/18/16545127/pendirian. rumah.ibadah.sumber.konflik.kerukunan. umat.beragama

Perwiranegara, A. (2008). Peranan Departemen Agama RI dalam 50 Tahun Indonesia Merdeka. In Artikel Trilogi Kerukunan (1st ed.).

Razi, K. (2007). SKB 1/1969: Perlukah Dicabut.
Jakarta: Kemenag RI.

Soemarni, V. (2006). Seputar Perumusan Peraturan Bersama Menteri No. 9 dan No. 8 Tahun 2006 Serta Penjelasannya. Jakarta: Kemenag RI.

Sukarjiman,. (2008). Kerukunan Hidup Antar Umat Beragama dalam Rangka Ketahanan Nasional (Master Thesis). Universitas Gadjah Mada.

Suryana, T. (2011). Konsep dan Aktualisasi Kerukunan Antar Umat Beragama. Taklim: Jurnal Pendidikan Agama Islam, 9(2).

Thantowi, J. (2006). Islam, Politik, dan Hukum: Esaiesai Ilmiah untuk Pembaruan. Yogyakarta: Balai Pustaka.

Whitney, F. (2000). A Four Year Continuaution Study of a Teachers College Class. New York: The Macmillan Co.

Wulandari, R. (2012). Ketika Rumah Ibadah Pun Tak Boleh Berdiri. Kompas.

Yewangoe, A. (2012). Agama dan Kerukunan. Jakarta: PT. Gunung Mulia. 